\title{
AUTOTEOORIA VÕIMALUSED TEOORIA JA OMAELULOOLISUSE VAHEL
}

\author{
RAILI MARLING
}

$\mathrm{T}$ änasel kirjandusmaastikul on kaubanduslikult edukate elulugude kõrvale üha enam ilmunud tekste, mis liiguvad hallis tsoonis, kus ilukirjanduslikku teksti sekkub tugev omaelulooline hääl, mis astub samaaegselt ka teoreetilisse diskussiooni. Žanride segamine pole iseenesest uus, kuid (auto)biograafia ja kirjanduse ristumise päevakajalisusest annab märku kas või tõik, et 2000. aastatel on inglise keeles ilmunud ridamisi romaane, mille peategelaseks on biograaf ning mille teemaks on seega piir fiktsionaalse ja faktilise vahel (Renders 2014: 30-31). Uus pole ka teoorialoome sidumine fiktsiooniga: oma romaanides on teoreetilisi arutlusi arendanud mitmed autorid, näiteks Alain Robbe-Grillet, Thomas Pynchon, Umberto Eco, Margaret Atwood, Malcolm Bradbury jt (selle kohta vt ka Ryan 2014). Autobiograafia ja teooria piire kompas samuti Roland Barthes. Selline žanriülene kirjutamine pole võõras ka Eestis, kui mõtleme Viivi Luige või Maarja Kangro tekstidele. Seega ei väida ma mitte, et tegu oleks uudse nähtusega, vaid et fiktsiooni, omaeluloolisuse ja teooria ristumiskohas kirjutatud tekstid võimaldavad tõstatada viljakaid küsimusi identiteedi, minaduse ja kirjanduse võimaluste kohta ning väärivad kirjandusliku praktikana lähemat tähelepanu.

Käesolevas artiklis huvitavad mind autoteoreetilisteks klassifitseeritavad tekstid, st suuremal või vähemal määral autobiograafilised tekstid, mis samaaegselt tegelevad teoreetiliste küsimustega ning mis žanride piirimaal seismisega proovivad teha nähtavaks muidu sõnastamatuks jäävaid fenomene (Young 1997: 64). Autoteooria võti on oma elukogemuse loov kujutamine, mis aga ei piirdu enda loo jutustamisega. Mieke Bal on autoteoreetilist lähenemist näinud spiraalse liikumisena oma loovtekstide, analüüsi ja teooria vahel (Bal 2015: 124). Sellises lähenemises saab autorist endast tekst või diskursus, „mis kirjutab maailma ja millele maailm ennast kirjutab", sealhulgas teoreetilise mõtte maailm (Kaufmann 2005: 577).

Väidan, et omaeluloolisus väärtustab subjekti, annab autoriteedi tema paigutatud kogemusele ${ }^{1}$ ning seega võimaldab küsida küsimusi, mida pelgalt teooria abil püstitada ei saa. Autobiograafiauuringute ajalugu on näidanud, et nimetatud väärtustamine on olnud valikuline. Näiteks naiste lugusid peeti kaua omaeluloolise subjektsuse normidest hälbivaiks ning neid kui tekste ei loetud piisavalt keerukaks, et neid tõsiselt analüüsida. Naiste autobiograafiad said autobiograafiauuringutes keskseks 1990. aastateks, sh erinevate subjektsuse teooriate arendamises (Smith, Watson 1998: 4, 16). Käesolev artikkel ei keskendu aga autobiograafiauuringute ajaloole, vaid pigem küsib, mida annab autobiograafilise elemendi lisamine teoorialoomele. Materiaalsus ja afektiiv-

${ }^{1}$ Sõna paigutatud viitab siinkohal feministlikus teoorias olulisele mõistele paigutatud teadmine (ingl situated knowledge), mis tuleb Donna Harawaylt ja viitab teadmise paratamatule seosele selle loomise ajalise ja ruumilise kontekstiga. 
sus on tänapäevase teoreetilise arutelu moeteemad, kuigi suurem osa sellest arutelust näib toimuvat sama elutus ja arusaamatus teoreetilises proosas kui paljukritiseeritud poststrukturalistlik mõte. Teooriat ja elu lepitavat kirjutamist näivadki selles kontekstis pakkuvat omaeluloolisusest inspireeritud hübriidsed kirjutamisvormid, nagu autoteooria.

Käesolev artikkel on teoreetiline arutlus selle žanri poliitiliste ja afektiivsete võimaluste üle, mida illustreerivad viited 2015. aastal ingliskeelses maailmas palju diskussioone tekitanud autoteoreetilisele tekstile, Maggie Nelsoni raamatule „The Argonauts” („Argonaudid”), ning sellest oma afektiivselt paigutatuselt kardinaalselt erinevale, eesti kirjanduse kontekstis mitmeid tabusid murdnud Maarja Kangro „Klaaslapsele” (2016). Varasem kriitiline vastukaja on Kangro teksti žanripiiride rikkumisele ka tähelepanu juhtinud: Maarja Hollo (2017: 133) nimetab seda dokumentaalromaaniks, Aija Sakova (2017) märgib, et see „tühistab igasugused piirid fiktsiooni ja omaeluloolisuse vahel", ning näeb teksti ka essee või arutlusena. Kahe teksti võrdlust õigustab mõlema aus ja kohati ebamugavust tekitav keskendumine emaduskogemusele, selleks et rääkida laiemalt naiste, viljakuse ja perekonnaga seotud normidest.

\section{Žanri, keele ja lugemisviiside piirid}

Žanride vahel liikumine on katse haarata nüüdisaegse kultuuri pidevas muutumises olemist, mida traditsiooniline teoreetiline analüüs ei suuda ehk retooriliste konventsioonide tõttu piisava nõtkusega jäädvustada (vrd Bal 2015: 124). ${ }^{2}$ Žanridel on oma reeglid ja piirid, retoorika ja toon, mida kasutades rääkijat või kirjutajat kuulda võetakse. Laurie McNeil vaatleb žanre teksti tõlgendamist suunavate „kultuuriliste stsenaariumitena” (tsiteeritud KurvetKäosaar 2016: 37). Carolyn Miller (1984: 153, 155) näeb žanri sotsiaalse teona (ingl social action) või konkreetsesse situatsiooni asetatud tegevusena, st fookuses on žanride pragmaatiline aspekt, see, mida nad võimaldavad teha. Pragmaatiliste aspektide hulka võivad kuuluda ka tekstide loodud emotsionaalsed ja afektiivsed registrid. Suzanne Keen ongi žanre nimetanud „afekte loovateks vaikimisi valikuteks" (tsiteeritud Felski 2011: 216). Teisisõnu on žanridesse sisse kirjutatud teatud eelistatud afektiivsed ja emotsionaalsed reaktsioonid (nt kui mõtleme armastus- või õudusromaanidele). Lisaks afektidele on žanridel ka väljakujunenud hääled. Õigusteadlane Richard Delgado rõhutab, et eriti akadeemilises diskussioonis on levinud surve, et kõik räägiksid ühe häälega. See hääl aga ei võimalda kõike öelda või öelda seda piisava intensiivsusega. Tema sõnul „kaotavad teatud valukarjed tõlkes üsna palju. Domineeriva õigusteadusliku väljenduse kogu idee seisneb selles, et piirata seda, mida saab väljendada, argumentide ringi, mida on võimalik esitada" (tsiteeritud Young 1997: 65).

Mis kehtib akadeemiliste tekstide kohta õigusteaduses, kehtib sama hästi ka kirjandus- ja kultuuriteoorias, kus küll räägitakse piiride ja kaanonite lõhkumisest, alustugede lammutamisest, tõdede küsimärgistamisest, aga tehakse seda üsna samasuguses abstraktses, keerulises, mittespetsialistile arusaamatus žargoonis. Selles keeles saab palju väita, kuid see keel on loodud intel-

\footnotetext{
${ }^{2}$ Bal kasutab oma tekstis sõna saamine (ingl becoming).
} 
lektuaalseks sparringuks, mitte emotsionaalseks kõnetamiseks. Sara Ahmedi (2004: 216) väitel aitavad aga just emotsioonid ühiskondlikel teemadel meile „naha alla” pääseda, meid puudutada, meid tegevusele suunata. Just selleks, et teooria kõnetaks ja raputaks, on mitmedki autorid kombanud akadeemilise diskursuse piire, toetunud pigem ilukirjandusele ja omaeluloolisusele, et teooriasse värsket verd süstida.

Praegusel teooriamaastikul on nii mõnedki uurijad sõna võtnud Paul Ricœuri sõnastatud „kahtluse hermeneutikast” välja kasvanud lugemisviiside vastu (Ricoeur 1970: 32). Rita Felski sõnul iseloomustab neid tõlgendusviise vastandav ja kahtlustav suhtumine teksti ning soov tekstidest „esile tuua ettekavatsemata tähendused, mis jäävad kättesaamatuks nii [tekstide] autoritele kui ka tavalugejatele" (Felski 2011: 216). Enamasti on kriitikanooled viimase kümnendi jooksul olnud suunatud poststrukturalismi vastu, kuid kriitikud ise pole kahtlustavast lugemisest priid; lihtsalt nende kriitikat iseloomustab metakahtlus, paranoia paranoia suhtes. ${ }^{3}$ Probleemiks pole siin teooriast tõukumine, mis on olnud väga viljakas kirjanduse uurimise viis, vaid see, kuidas teooriaga suhestutakse. Väidan, et omaeluloolisusele üles ehitatud autoteoreetiline tekst aitab vältida kahtluse hermeneutikast lähtuva akadeemilise kirjutamise puudujääke, eelkõige ranget eristust teooria ja praktika, konkreetsesse situatsiooni asetatud elukogemuse vahel.

Näiteks Eve Kosofsky Sedgwicki, poststrukturalistliku teooria ühe suurkuju sõnul raskendavad abstraktsele teoreetilisele arutelule omased lugemisviisid „kohalike, sattumuslike seoste avamist mingi konkreetse teadmise ning selle narratiivsete/epistemoloogiliste tagajärgede vahel, mis puudutaksid vastava teadmise otsijat, teadjat või edasiandjat" (Sedgwick 2003: 124). Nende asemele pakub Sedgwick (2003: 150-151) ravivat (ingl reparative) lugemist, mis tunnistaks igapäevaste emotsionaalsete repertuaaride rikkust. Just kartus, et kahtluse hermeneutika piirab meile võimalike lugemiste arvu, teeb kõik analüüsid üheülbalisteks ning kaotab võime meid üllatada, seda nii teoreetilisel kui ka kirjanduslikul tasandil, kannustab mitmeid selle kriitikuid (Felski 2011: 231). Kuna noor põlvkond lääne teadlasi on üles kasvanud selle teoreetilise keelega, siis pole üllatav, et selle vastu täna nii mitmest vaatenurgast kriitikat esitatakse - nt praegusel hetkel väga populaarses afektiteoorias, aga ka teaduskirjanduses laiemalt, kus autori surma asemel on klišeeks muutumas hoopis teooria surm (vt Gregg, Seigworth 2010). ${ }^{4}$ Negatiivsuse eitamine ise ilmtingimata positiivset platvormi ei loo ja võib jääda pelgaks akadeemiliseks žestiks. ${ }^{5} \mathrm{Ka}$ afektiteoorial on juba tekkinud omad eelistatud viitesarjad ja uurimisobjektid, mis selle lähenemise värskust vähendavad. Samuti tasub märkida, et kahtluse hermeneutikat kritiseerivad tekstid on jäänud rääkima samas kahtluse ja abstraktsuse keeles. Just akadeemilise stiili poliitika on käesoleva artikli huviobjektiks.

\footnotetext{
${ }^{3}$ Juba tsiteeritud Rita Felski artikkel on selle lugemisviisi hea kaitse, sest vastukarva lugedes avanevad tekstide süvakihistused. Lääneriikides on see viimased paar aastakümmet olnud normatiivne kirjanduse lugemise viis ning seega on tema uuenduslik potentsiaal vähenenud (vt Felski 2011: 227). Eesti olukorras see kriitika ei kehti, sest meil on poststrukturalismist mõjutatud kirjandusteadus noor, seda toetava teoreetilise tekstistiku tõlkimine sai hoo sisse alles 1990. aastatel.

${ }^{4}$ "Teooria surma” kohta vt nt Ryan 2014 või Patai, Corral 2005.

${ }^{5}$ Afektiteooria kriitiliste silmaklappide kohta vt Hemmings 2005: 563. Afektiteooria uudsuse eriti feministliku kriitika kontekstis on küsimärgistanud nt Fischer 2016.
} 
Teooria stiil on rõhutatult abstraktne, distantseeritud, uhke oma hermeetilisuse ja arusaamatuse üle. Akadeemilises maailmas enese kehtestamiseks peame selle kriitilise keele teise keelena omandama (esimese, emakeelena, ei räägi seda keegi), sest see on sellieksam, millega meid akadeemilisse kogukonda vastu võetakse. Kuid me ei kipu piisavalt sageli küsima, mida me selles keeles teha saame, ega ka seda, mida me selles keeles teha ei saa.

Selle impulsi ehk üks kirglikumaid väljendusi on ameerika kirjandusteadlase ja -teoreetiku Jane Tompkinsi 1987. aastast pärinev essee „Mina ja minu vari”. Essee algab kõnekate lausetega:

Minus on kaks häält... Üks on kriitiku hääl, mis soovib parandada viga essee epistemoloogiakäsitluses. Teine on inimese hääl, kes soovib kirjutada oma tunnetest. (Ma olen tahtnud seda kaua aega juba teha, kuid ma olen lihtsalt liiga suurt piinlikkust tundnud.) [---] Olgu, ma olen väsinud konventsioonidest, mis hoiavad epistemoloogia või James Joyce’i käsitlust lahus mõtisklustest selle üle, mis toimub minu akna taga või minu südames. Avaliku-isikliku dihhotoomia, see tähendab õieti avaliku-isikliku hierarhia, on naiste allutatuse eeltingimus. Ma ütlen, põrgusse sellega. (Tompkins 1987: 69)

Tompkins seletab, kuidas meid on õpetatud kartma isiklikku, eriti naisteadlaste puhul, sest naisi on ajalooliselt kahtlustatud kriitilise ratsionaalse reflekteerimisvõime puudumises (vt nt Jaggar 1989). On ju akadeemilisel keelel alati mehelik hääl. Fantaasiakirjanik Ursula Le Guin on seda nimetanud isakeeleks, mis ei taotle ainult objektiivsust, vaid ka distantseerimist, „lõhe, ruumi loomist subjekti või mina ning objekti või teise vahele" ning mis vastandub seoseid loovale emakeelele (tsiteeritud Tompkins 1987: 173-174).

Keele poliitika, keele piiride mõtte on eriti teravalt üles võtnud erinevad feministlikud autorid, kes 1970.-1980. aastatel vaidlustasid personaalse ja poliitilise vahelise eristuse. Feministlik kriitika soovis hakata vastu monoliitsetele, ette paika pandud isakeelsetele parameetritele, mis piirasid võimalusi rääkida isiklikust ja isiklikult. Sooviti jäädvustada seni vaigistatut ja puudunut. Selline kirjutus julges olla isiklik ja haavatav, proovides saavutada „kunstile omast väge ja väärikust" (vt nt Showalter 1981: 189). Feministlik kirjutus pürgis 1980. aastatel kirjutama teisiti, rõhutades autorite paigutatust ajas ja ruumis, nagu seda tegi ameerika luuletaja Adrienne Rich oma essees asukoha poliitikast (ingl politics of location), milles ta hoiatab „elusate inimeste tegemistest lahutatud abstraktsioonide eest, mida neile loosungitena sisse söödetakse". Kõnekalt võrdleb ta teooriat kastega, mis maapinda niisutab, kuid meenutab, et kui teooria enam maapinna järele ei lõhna, st kui ta on muutunud liiga elukaugeks, siis pole sellest enam kasu (Rich 1986: 213). Feministlik kriitika ja naiskirjutus kutsusid leidma uut (akadeemilise) väljenduse keelt.

Tänaseks teame, et see soov osutus utoopiliseks. Kui feministlik teooria ja soouuringud astusid üle akadeemilise legitiimsuse läve, võtsid nad üle isakeele ja tänaseks on feministlik teooria lugejast sama irrutatud kui mis iganes teinegi teooria. Feminismi poliitika järele tundis Toril Moi kirjanduskriitilistes tekstides puudust juba aastal 1988 (vt Moi 1988: 4). 1990. aastatel oli peamiseks kriitika objektiks feministlikuski mõttes domineerima hakanud poststrukturalism oma teoreetilise ekvilibristikaga, mis küsimärgistas val- 
gustusaja mõtte kriitikas muuhulgas ka feminismi alustalad. ${ }^{6}$ Poststrukturalistliku ja feministliku mõtte sobitamise võimalustele on pühendatud kümneid tuliseid feministlikke vaidlusi, millest üks on isegi avaldatud eesti keeles (Nicholson 2006). ${ }^{7}$

Sellest tõusetub aga oluline teema, mille sõnastas samuti juba 1980. aastatel ameerika kirjanik Audre Lorde (1984), nimelt kas isanda tööriistu saab kasutada isanda maja lammutamiseks. Kas isakeeles kirjutatud teooria saab lõhkuda hierarhilist ja binaarset mõtlemist? See ei tundu tänapäeval küll uudse mõttena, kuid tekstid, millele selles artiklis toetun, on jätkuvalt värsked, sest tegelikult on mitmed 1980. aastatel tõstatatud küsimused feministliku kirjandusuurimise ja teooria maastikul rahuldavalt lahendamata. Sellele on viimasel kümnendil mitmetes oma kirjatöödes tähelepanu juhtinud Toril Moi (2015). ${ }^{8}$ Puhtalt teooria tasandile jäädes ei suuda feministlik kriitika aga lugejat veenda, et tal on reaalses maailmas reaalsete probleemidega silmitsi seisvatele naistele ja meestele pakkuda midagi kasulikku või kasutatavat. Selleks peaks ta otsima uusi teoreetilisi, aga ehk ka stilistilisi lätteid (Moi 2006). Nancy K. Miller (1991: 113) rõhutab ju esteetika moraalsust, st kirjanduslikkuse ja poliitilisuse (nt soo- või rassipoliitika) seotust.

\section{Autoteooria kui paigutunud tekstiloome}

Minu jaoks pole üllatav, et viimasel ajal on feministlikud uuringud üha enam huvitunud autobiograafiast. Vaatlen selles artiklis autoteooriaks klassifitseeritud žanri ühe sellise huvi näitena. Autoteooria tähistab teoorialoomet, milles ei ole alla surutud kirjutavat häält ega tema elukogemust. Youngi (1997: 69) sõnul nõuab see paigutatust ja kehalisust: nii autor kui ka lugeja peavad tunnistama oma kehalist asetsemist ruumis ja sotsiaalses struktuuris. Nagu Adrienne Rich (1986: 213) märgib, on abstraktsus suureline, privilegeeritud ja hõljub reaalse inimkogemuse kohal. Viimasest aga ei peaks me proovima mitte üle saada, vaid see tuleks tagasi võita. Rich näiteks sooviks teoreetilistes tekstides ajutiselt keelustada sõna „keha” abstraktne kasutamine, sest, nagu ta kirjutab:

Kui ma kirjutan „keha”, ei näe ma midagi konkreetset. Kui kirjutan „minu keha” siis sukeldun ma elatud kogemusse, konkreetsusse: ma näen arme, vigastusi, värvimuutusi, kahjustusi, kaotusi, aga ka seda, mis mulle rõõmu teeb. [---] Kirjutades „minu keha”, väheneb ahvatlus esitada grandioosseid väiteid. (Rich 1986: 215)

Autoteooria lõhub ühelt poolt akadeemilises kirjutamises kohustusliku objektiivse, külma, kriitilise distantsi nõude, aga Youngi sõnul teisalt õõnes-

${ }^{6}$ Sellel teemal kirjutatud raamatute ja artiklite arv 1990. aastatel on äärmiselt suur. Mainin seetõttu vaid paari tuntud näidet: Modleski 1991; Alcoff 1988. Eelmises viites toodud Moi essee haakub samuti selle debatiga.

${ }^{7}$ Inglise keeles ilmus raamatu algne variant aastal 1995, nende debattide tipphetkel. Tänaseks on see debatt raugenud, kuna poststrukturalistlikud lähenemised muutusid 1990. aastatel domineerivaks, koos postkoloniaalse ja intersektsionaalse mõttega. Selle debati uut lainet võibki tunnetada praegustes arutlustes afekti ja materiaalsuse üle.

${ }^{8}$ Inglise keeles ilmus artikkel aastal 2008 ajakirjas Feminist Theory. 
tab mingi määrani ka traditsioonilist autobiograafilist impulssi, mille kohaselt iga elu on individuaalne. Pigem rõhutab autoteooria elude omavahelist seotust, minaduse suhestumuslikkust. Nii riivab autoteooria Adriana Cavarero minaduse mudelit, mida on Eestis varem tutvustanud ja kasutanud Leena Kurvet-Käosaar. Selle kohaselt vajab mina enda kõrvale teist, sest tema „unikaalsus saab väljenduda vaid ilmnemise kaudu teis(t)ele”, mis on omakorda seotud meie ihaga saada jutustatud, ihaga „loona ilmneva ühtsuse järele" (tsiteeritud Kurvet-Käosaar 2016: 41-42; tervikteksti vt Cavarero 2000). ${ }^{9}$ Lisaks sellele rõhutab autoteooria seotust ajaloo ja mitmetasandiliste võimusuhetega. „Enamgi veel, liikudes jutustajate/autorite kui indiviidide ja suuremate sotsiaalsete jõudude vahel, mis neid valitsevad - ja mida nad püüavad muuta -, on need tekstid ise sellesama poliitika näited, mida nad kaitsevad" (Young 1997: 69). Selles protsessis kutsutakse lugejat üles mitte ainult jutustava mina fragmentaarsest kogemusest lugu konstrueerima, vaid ka enda, oma minaduse ja oma paigutatuse üle mõtlema. Selline refleksioon on tänapäeva sotsiaalteadustes tavapärane, aga ei pruugi laieneda kasutatavale stiilile.

Stiil on aga muuhulgas ka poliitiline. Distantseeritud akadeemilise keelega käib kaasas n-ö autoriteediefekt, mis varjab kirjutaja haavatavust, kehalisust, tundeid, paigutumist aegruumis ja ideoloogilises plaanis ega tunnista teise isiku kohalolu. „Autoriteetne hääl räägib, nagu poleks teist inimest olemas. Või ehk korrektsemalt, ta ei suvatse ette kujutada, kes võiks meie juttu kuulata" (Tompkins 1987: 175-176). Rachel Blau DuPlessis (2009: 22) meenutab, et feministliku teadmisloome üheks oluliseks saavutuseks on objektiivsuse ümbertähistamine, st „väljakutse esitamine normatiivsele professionaalsusele, mis surub alla kire ja mis teoretiseerib ilma pragmaatilise seoseta materiaalse või empiirilise teadmisega". Selle vastandiks ei ole mitte subjektiivne, vaid kaasatud, intersubjektiivne mõtlemine. Just see on põhjus, miks paljud feministlikud autorid on juba aastakümneid pöördunud personaalse kriitika poole, mida käesolevas tekstis nähakse autoteooria esiemana (termin pärineb Miller 1991: 1). Personaalse kriitika üheks heaks näiteks ingliskeelses maailmas on Nancy K. Miller, kes on kogu oma akadeemilise tegevuse jooksul kasutanud erinevaid segavorme, mis lõimivad isiklikku kogemust teoreetilise aruteluga. Juba ülal tsiteeritud raamatu esseedeski seob Miller emaga kaubamajas käimist või isa vananeva keha vaatamist laiemalt soo, mäletamise ja võimu küsimustega. ${ }^{10}$

Kuigi Tompkins esitas oma manifesti väljakutsena teooriale, ei ole tänane autoteoreetiline praktika kindlasti teooriavastane. Pigem on eesmärgiks teooria n-ö tagasivõitmine, „selle pööramine tema enda vastu” (Miller 1991: 5) või teooria tagasi toomine kirjutava, lugeva ja kogeva subjekti juurde. Nagu kirjutas Sedgwick (1987: 137), kes elu lõpuaastail pöördus personaalsema kirjutamise juurde, ühes oma autobiograafilises essees: „Üks ajendeid sel teemal kirjutada on olnud fantaasia, et lugejad või kuulajad saavad siit erinevaid stiimuleid - vihastavad, samastuvad, rõõmustavad, kadestavad, saavad „loa”, tunnevad end väljajäetuna - „samasuguste” kirjelduste kirjutamiseks, mida

\footnotetext{
${ }^{9}$ Leena Kurvet-Käosaar on Adriana Cavarero minakäsitlust tõhusalt kasutanud samuti žanride piiril asetseva Viivi Luige „Varjuteatri” analüüsiks.

${ }^{10}$ Uuemates tekstides liigub Miller aga soo ja feminismi teemadest eemale. Nt tema raamatus „Mida nad alles hoidsid” (What They Saved”, 2011) tõukub arutelu isa surma järel leitud esemetest, mis lubavad autoril mõtiskleda immigratsiooni, juurte ja mälu teemal.
} 
see ka ei tähendaks, ja jagavad neid." Selline teooria ei sulge lugeja ees uksi. Teda ei huvita külm distants, vaid suhestumuslikkus, sekkumine, segamine, ärgitamine.

\section{Autoteoreetiline praktika Maggie Nelsoni ja Maarja Kangro töös}

See teoreetiline küsimustekobar ongi mind toonud nüüdisaegsete hübriidsete tekstide juurde, mis taotlevad teoreetilist teadmist tugevaid omaeluloolisi impulsse kasutades. Viimase viie aasta jooksul on inglise keeles avaldatud mitmeid tekste, mis seovad omaeluloolisust filosoofia, psühholoogia, teooria ja ühiskonnakriitikaga (nt Preciado 2013; Kapil 2015; Nelson 2015). Need tekstid segavad autobiograafilist kriitikat, kehateooriat, kriitilisi memuaare, ja kirjastajad klassifitseerivad neid tavaliselt žanriülestena. Nagu Preciado oma tekstis kirjutab: „... see raamat pole memuaar. [---] Keha-essee. Tegelikult fiktsioon. Kui just peab asju äärmuseni viima, siis on see kehapoliitiline fiktsioon, teooria mina kohta või mina-teooria" (Preciado 2013: 11). Nagu autor isegi rõhutab, ei ole tema tekst memuaar selle tavapärases tähenduses, vaid pigem fiktsioon autori muutuva mina kohta, mis võimaldab autoril arendada laiemat teoreetilist debatti. Sellises tekstis ei vaadata mina isolatsioonis, vaid suhtes laiemate ühiskondlike jõujoontega. Preciado ise rõhutab, et teda ei huvita oma emotsioonid nende individuaalsuses, vaid see, kuidas need lõikuvad teiste kogemustega (Preciado 2013: 11). ${ }^{11}$ Sellelt pinnalt arendatud isiklik teooria suudab potentsiaalselt kõnetada teisi subjekte ja ärgitada teoreetilis-poliitilist debatti. Just seepärast on Preciado töö autoteoreetiline.

Järgnevalt tahaksin eespool toodud teoreetilise arutelu selgitamiseks näitena kasutada 2015. aastal inglise keeles ilmunud ja kriitikutelt palju positiivset tähelepanu saanud Maggie Nelsoni segažanrilist teost „Argonaudid”. ${ }^{2}$ Raamatu sisu on lihtne: Nelson kirjutab oma suhtest soovahetusoperatsiooniks valmistuva ja seda läbi tegeva elukaaslasega, nende abielust ja lastest. Kuigi pere, abielu ja laste saamine on igapäevased nähtused, loetakse neid selles raamatus vastukarva, sest tegu on ebakonventsionaalse perekonnaga, kelle kooselu, rääkimata abielust, ei mahu paljude inimeste tavapärasesse perekonnamudelisse. ${ }^{13}$ Tegu on seega ühtaegu mitmes mõttes konservatiivse ja samas ülimalt radikaalse tekstiga, kuna see võib mingi astmeni meenutada peavoolukultuuri emadusmemuaare, kuid pöörab samas nende keskmes olevad soolised ideed pea peale. Nelson kirjutab emaduskogemusest, selle keha-

${ }^{11}$ Preciado analüüsi fookuses on ilma arstide järelvalveta võetud testosterooni mõju tema kehale. Preciado mikropraktikate võimalikule neoliberaalsele depolitiseeritusele on nt viidanud Helen Hester [2013]. Preciado teksti biopoliitika analüüs pole aga antud artikli eesmärgiks.

${ }^{12}$ Nelsoni raamat figureeris kümnete väljaannete aasta parimate raamatute nimistus ning võitis muuhulgas USA kirjanduskriitikute professionaalse ühingu (National Book Critics Circle) aastapreemia kriitika vallas.

${ }^{13}$ Nelson ise kasutab enda ja oma pere kirjeldamiseks läbivalt sõna queer, mis on ingliskeelses maailmas viimase kümnendi jooksul liikunud sooteoreetikute tekstidest peavoolumeediasse ja igapäevakeelde. Sellega tähistatakse igasuguseid binaarse ja heteroseksuaalse soonormiga mittesamastuvaid seksuaalsuse vorme ning ka inimesi ja praktikaid, mis eitavad fikseeritud soolise ja seksuaalse identiteedi olemasolu. Kuna analüüsi fookuses pole mitte niivõrd autori sooline või seksuaalne enesedefinitsioon, kuivõrd tema kirjutamispraktika, kasutan seda võorlaenu võimalikult vähe. 
lisusest, samas dekonstrueerides normatiivset reproduktiivset seksuaalsust. Nelson ootab last, kuid Nelsoni elukaaslane alustab samal ajal meditsiinilist soovahetust, seega on teksti keskmes mõtisklus keha ning keha ja mina ebastabiilse, pidevas muutumises oleva suhte üle, aga ka suhete üle mina ja teiste vahel.

Nelsoni romaani poliitilisele, kuid olemuselt optimistlikule tonaalsusele vastandub teravalt Maarja Kangro 2016. aastal ilmunud omaelulooline romaan „Klaaslaps”, mis vaatleb sarnast küsimustekobarat, ehk siis mida tähendab naisele, eriti loovale naisele, lapse saamine, kuidas suhestuvad tema sisemised soovid ja neid ümbritsevad ühiskondlikud normid. Kangro teksti afektiivne vägi on aga hoopis teine, kuna kauaoodatud, kuid ilma koljuluudeta laps jääb sündimata ja minajutustajal pole isegi võimalik teda maha matta. Individuaalsest valust kasvab välja mõjus, Eesti oludes paljusid tabusid lõhkuv refleksioon viljakuse, emaduse ja sellega seotud sundide üle. ${ }^{14}$ Lugu on väga isiklik, aga samal ajal puudutab mitmeid soopoliitilisi teemasid.

Nelsoni raamatu pealkiri viitab müütilistele argonautidele. Selles Roland Barthes'ilt laenatud mõtteeksperimendis küsitakse, kas laev, mille kõik osad on reisi jooksul välja vahetatud, on tagasi kodusadamasse jõudes seesama laev - või kaudselt, kas inimene, kelles on toimunud põhimõtteline muutus, on seesama inimene. Mis määratleb minaduse ja mina suhestumise teisega, keda ennast teatakse armastavat, aga kelle olemus muutub? Barthes kasutab Argo kujundit kui strukturalistlikku allegooriat objektile, mille on loonud asendamine ja nimetamine. Sadamasse naaseb laev, mille kõik osad on vahetatud, aga me nimetame seda endiselt Argoks. Kirjandustki näeb Barthes omamoodi Argona, sest tekstidel on muutumatu funktsioon või nimi („objekti olemus”), kuid iga üksikut osa uuendatakse lõputult (Barthes 1972: xvii, 153). ${ }^{15}$

Käesoleva artikli jaoks huvitavalt naaseb Barthes Argo kujundi juurde oma fiktsionaliseeritud autobiograafias, ${ }^{16}$ kus ta seda kujundit mitmel korral kasutab ja jõuab järelduseni, et nimi pole seotud osade stabiilsusega (Barthes 1977: 46). R. B.-d ja raamatus olevat Roland Barthes'i seob tegeliku Roland Barthes'iga vaid nimi. Barthes kasutab kirjaniku paralleelina kalmaari, kes toodab tinti, nii nagu kirjanik toodab kujundite ja märkide kombinatsioone, mis aga kumbki ei aita objekti paremini fookusse tuua, vaid pigem teda tindipilve matta (Barthes 1977: 162). Argost saab teksti analoog. Kogemus on katkendlik, kuid nimetamine aitab luua stabiilsustunde. Argonaut saab Barthes'i jaoks ka ideaalseks armastavaks subjektiks, kes ikka ja jälle kordab sama lausungit (Barthes 1977: 114). Barthes'i huvitab kõne, milles saavad koos eksisteerida samasus ja erinevus, sest kuigi nimetamine ja asendamine aitavad kogemuse katkendlikkust varjata, soovime me subjektidena keelt, mis otsesemalt kujutaks iha järjepidevust. Barthes kui kirjanik, nagu märgib Paul John Eakin (1992: 16), pole külm teoreetik, vaid selles tekstis näeme tema rahutut mõtiskelu enese kujutamise võimaluste üle.

${ }^{14}$ Nii Hollo kui ka Sakova viitavad Kangro tekstist rääkides itaalia kirjaniku Oriana Fallaci raamatule „Kiri sündimata jäänud lapsele”.

${ }^{15}$ Argo kujundit kasutab Barthes, vastates ajakirja Tel Quel küsimustele kirjanduse hetkeolukorra kohta.

${ }^{16}$ Seda on nimetatud nii postmodernistlikuks autobiograafiaks kui ka anti-autobiograafiaks, vt nt Eakin 1992: 20. Prantsuskeelses originaalis ja ka ingliskeelses tõlkes on tiitellehe pöördel Barthes'i enda käega kirjutatud fraas, et teksti tuleb vaadelda kui romaanitegelase suu kaudu räägitut. Sellele fraasile räägivad vastu nii autori käekirja kasutamine kui ka raamatut illustreerivad ohtrad perekonnafotod. 
Nelson ei kasuta Argot kirjanduse, vaid muutuva ja samas suhestumusliku mina olemuse üle mõtisklemiseks. Kui Barthes on tindipilve kaduv kalmaar, siis Nelson proovib muutuvas identiteedirägas leida teistele ilmnevat mina. Tema tekstis on mitmes kohas rõhutatud iha jutustada teiste lugu ja samal ajal saada ka ise jutustatud. Viimane pole aga turvaline tegevus, sest üks Nelsoni varasemaid raamatuid - samuti hübriidne „Jane: A Murder” („Jane: mõrv", 2005) - käsitles tema ema õe mõrva ja selle avaldamise järel sattus ta vaimselt haige võõra ebaterve huvi objektiks. Nelson teab, et omaelulooline jutustamine puudutab teisi elusid ning on teatud laadi sotsiaalne tegu, millel on oma afektiivsed ja kogemuslikud tagajärjed. Žanri pragmaatika, kuigi Nelson ise neid sõnu ei kasuta, jookseb läbi tema teksti.

Ka Kangro teksti kannab soov saada jutustatud ning temagi seisab silmitsi küsimusega, mismoodi elada edasi pärast traumat, mis toob kaasa luhtumise ja lootusetuse tunde, sest kadunud on lihtsameelsete kujutuste turvaline vatt, mida me enda ümber paigutame, et maailma julmusega hakkama saada (Kangro 2016: 14). Mis saab inimesest - või täpsemini naisest - kellel puudub järeltulijates, „oma inimestes” (Kangro 2016: 55), väljendatud tulevik? Ta on väliselt sama inimene, kes sööb rostbiifileiba, kuid kes sisimas teab, et „[k]ui surmale mõelda, on kõik naeruväärne” (Kangro 2016: 204).

Barthes'i Argo kujundi juurde toob Nelsoni nii huvi mina jutustatavuse kui ka iha järjepidevuse vastu. Kui meie kogemus on katkendlik, kui meie ja teise mina on pidevas muutumises nagu Argo, siis kuidas on võimalik armastatu nime lausudes kindel olla, kes on see, kelle vastu iha tuntakse? „[K]ui armastaja lausub fraasi „ma armastan sind”, siis tuleb iga kasutuskorra ajal selle tähendust uuendada..." (Nelson 2015: 5). Antud tekstis on sellel muutumise-samaksjäämise dilemmal väga konkreetne tähendus: Nelsoni ja tema elukaaslase keha ujutavad üle uued hormoonid, mis neid muudavad, ja seega tekib paratamatult vajadus küsida, kes on see, kelle vastu armastust tuntakse, mis on siiski see muutumatu ise, mis jääb samaks. Kangro teoses paneb sama küsimust esitama sügav trauma, aga ka küsimus, milline on lapsevanema armastus tekkiva uue elu vastu, „[a]rmunu pilk bioloogilisele ollusele”, ka siis, kui laps pole selline, nagu oodati (Kangro 2016: 188).

Barthes'i abstraktse aruteluga võrreldes on Nelsoni tekst kehaline ja afektiivne. Armastuse enda reaalsus ei vaja tõestamist, selles on jutustav mina läbivalt kindel. Küsimusi tekitab see, kuidas tähistatava ja tähistaja libisemisele, nime ja seda kandva inimese mittesobitumisele reageerib ühiskond, mis eeldab identiteedi, nime ja isiku fikseeritust. Mitmel korral tekstis kujutab Nelson stseene, milles tema elukaaslase krediitkaardil esineva nime ja kaarti kasutava füüsilise isiku mittesobitumine tekitab ebamugavaid olukordi, seda mitte autori ja tema elukaaslase jaoks, vaid just enese normatiivsust ja teise normist hälbimist aduva inimese jaoks. Sellised näited avavad teksti autoteoreetilise potentsiaali: fookuses on oma elust laenatud episoodid, mille juurest autor spiraalselt liigub teoreetilise paralleeli juurde, vaagib seda ning täiendab teoreetilist mõtet kogemuse nüansseeritud analüüsiga. Oluline pole teooria arendamine, vaid kogemusele mõtte otsimine, mille juurde tekstis erinevatest rakurssidest tagasi tullakse.

Ka Kangro tekst on kirjutatud sügavalt isikliku afektiga, milles minajutustaja halastamatult kirjeldatud valu saadab poolirooniline kõrvaltpilk, sest ta on „nii sügaval põrgus või perses, kus ei nuteta” (Kangro 2016: 12). Ei 
emotsioonid ega ratsionaalne mõtlemine ole sünkroonis meid tabavate uudiste või kogemustega ning see irooniline kõrvaltpilk meenutab ausalt seda lünka.

Toetudes Argo muutuvale, kuid samal ajal püsivale olemusele, näeb Nelson muutumist mitte mingisse konkreetsesse lõppsihtmärki jõudva tegevusena, vaid pideva protsessina, mida aga meid ümbritsev ühiskond proovib kuidagi määratleda, pildistada ja sildistada alates praktiliselt inimese eostamishetkest. Nelson kommenteerib seda, kui ta järjekordselt ultrahelisse saadetakse: „Laske tal oma lootekotis ringi keerelda, jumal hoidku.... Laske tal jääda teadmatusse - ehk esimest ja viimast korda - sellest, et ta on kohustatud teistele oma mina esitama, sellest, et me areneme, isegi emaüsas, reageerides ootuste ja peegelduste voole, mis meid pommitab. Lõpuks nimetame me seda lumepalli minaks (Argoks)" (Nelson 2015: 94-95). Selles episoodis naaseb Nelson pinge juurde, mis tekib inimese unikaalsuse ning ühiskonna soovitud arusaadava, selgelt kirjeldatava sildi vahel. Selles spiraalina liikuvas autoteoreetilises arutelus puudutab Nelson identiteedipoliitikat ja sooteooriat, kuid seda mitte akadeemilises žargoonis, vaid kogemusekeskselt. Tegelikult vormuvad kõik edaspidi tsiteeritud näited üheks terviklikuks, edasi-tagasi liikuvaks autoteoreetiliseks mõttetööks mina ja identiteedi teemal. Need mõtted rulluvad lahti eriti raseduse ajal, mil naine ja tema keha on erilise ühiskondliku huvi (ja ehk ka järelevalve) objektiks. ${ }^{17}$

Nelsoni jaoks on normisunnid ja väljastpoolt tulevad määratlused naiseks olemise puhul tavalised, kuid need intensiivistuvad eriti raseduse ajal, kui ta ise proovib laveerida nii heteronormatiivsete kui ka queer-kogukonnas „normaalse” emaduse ja perekonna kohta käivate reeglite väljal, et säilitada oma mina ja defineerimatult muutuvat kogemust. Ka peavoolukultuuri vaidlustavad rühmad loovad oma norme ja definitsioone, mis kogemust oma reeglite järgi painutada soovivad. Normatiivse heteroperekonna kõrval võib eksisteerida sama normatiivne samasooliste perekond. See, mida peetakse normaalseks ja mida hälbeliseks, pole kaugeltki selge, küll aga on tunda iha selgust loova sildi järele. Nelson küsib näiteks, kas rasedus, see näiliselt heteroseksuaalse normaalsuse tipp, pole mingis mõttes hälbiv, „...kuna see muudab sügavalt inimese „normaalset” olekut ning toob kaasa radikaalse intiimsuse oma kehaga - kuid samal ajal ka radikaalse võõrandumise oma kehast? Kuidas saab üks kogemus, mis on nii sügavalt imelik ja metsik ja muutev, ühtlasi sümboliseerida ja kehtestada kõige suuremat konformismi?" (Nelson 2015: 13-14)

Rasedus paneb Nelsoni kogemuse külge näiliselt selge, kindlust andva sildi, mis surub alla raseduse kui sellise häirivuse, segasuse, vastuolulisuse. Nelson astub oma tekstiga rikkalikule ja samal ajal väga vastuolulisi seisukohti sisaldavale feministliku teooria väljale. Feministide seas puudub sellel teemal üksmeel; on neid, kes näevad rasedust naist kehaga samastava ja immanentsusesse suruva nähtusena (nt Simone de Beauvoir), teised on näidanud rasedusega kaasnevat lõhestunud subjektsust (nt Iris Marion Young), kolmandad on rasedusele toetudes arendanud alternatiive lääne filosoofias ülistatud ühtsele minale (Adrienne Rich, Luce Irigaray, Sara Ruddick). ${ }^{18}$

17 Vt nt Balsamo 1996; selle kohta, millist distsiplineerivat mõju avaldavad nt rasedusteemalised käsiraamatud, vt Seigel 2013.

${ }^{18}$ Vt nt Young 1984; Rich 1976; Irigaray 1985; Ruddick 1995. Mitmed loetletutest on raseduskogemuse kirjeldamiseks tihti kasutanud esimest isikut (sh filosoof Iris Marion Young). 
Feministlikud autorid on oma töödes eelkõige püüdnud näidata, kuivõrd on loomulikuks peetav rasedus läbi imbunud kultuurist ja selle normidest. Nelsoni raamat pole seega feministlikus kirjanduses iseenesest uus, kuid vaatleb rasedusnarratiivi, tõukudes tänapäevastest soopoliitilistest debattidest. ${ }^{19}$

Kangro puhul on raseduse ja laiemalt naise viljakuse lahtimõtestamine keerukam, sest rasedus ei lõpe õnnelikult. Rasedus on kummaline, kuna toimib ühiskonna silmis normeerivana. Rasestununa tunneb minajutustaja ennast nagu „Frankensteini koletis, kes on äkki muutunud pärisinimeseks” (Kangro 2016: 14). 41-aastane esmarase, kes on kasutanud kunstlikku viljastamist, on meedikute silmis normihälve. Minajutustajat ei raputa aga ühiskonna sildistav pilk, vaid läbiv enesesüüdistus sündimata lapse ees, keda ta ei suutnud päästa, "[k]es sinu sees, sinu pärast jubedaks biomassiks moondus" (Kangro 2016: 177). Kangro minajutustaja teab, et tegelikult on tema kui autori edasielamine võimalik tekstiloome kaudu „märksa tugevam ja sisukam positsioon", kuid ta ei saa ennast lahti mõelda soovist emaduse kaudu vabaneda omaenda minadusest, objektistuda (küll mööndes selles soovis oma privileegipimedusest tulenevat naiivsust) (Kangro 2016: 54, 56). Nagu minajutustaja sõnab, „ma muidugi petsin iseennast. Olin sedavõrd harjunud subjektne olema, et oma tahte pidev allasurumine tundus eksootiline" (Kangro 2016: 56). Tema tekst on selgelt teadlik meie konkreetsest aegruumist tulenevate ühiskondlike sundide, meie kõvakettale salvestatud kustutamatu „biofašistliku konservi” mõjust meie intiimseimatele soovidele (Kangro 2016: 53). Kangro julgeb küsida, „[m]illine naine ei eelistaks Platoni või ajalehe lugemist imiku jauru vaigistamisele? Ühiskonna, traditsiooni nui peab olema päris kõvasti talle pähe lajatanud, kui ta väidab, et eelistab jauru. Siiralt ütleb mõni mõtlematuke seda võib-olla enne, kui jaur tegelikult käes on.” (Kangro 2016: 57)

Kangro teksti vägi tulenebki sellest, et ta on teravalt teadlik ühiskondlikest normidest ja tabudest, mis emadust ümbritsevad, aga see ei muuda tema soovi lapse kaudu tekkiva teistsuguse tuleviku järele. See, et me oleme normidest teadlikud, ei tähenda, et need meid ja meie kehasid ei mõjutaks, et me suudaksime selgelt eristada oma mina ja normide diktaati. Kangro teksti teeb huvitavaks just see teravalt usutavaks kirjutatud pinge.

Nelson räägib enda ja oma elukaaslase väga personaalsest kehalisest kogemusest, kuid seob seda ühelt poolt ühiskonnakriitikaga (feministlikust ja queer-vaatepunktist) ja teisalt, ilma traagelniite näitamata, rea teoreetiliste refleksioonidega Roland Barthes'ilt, Susan Sontagilt, Eve Kosofsky Sedgwickilt, Julia Kristevalt, Judith Butlerilt ja mitmetelt teistelt teoreetikutelt. Me ei kohta nende teoreetikute keerukaid tsitaate, vaid Nelsoni enda arutluse kõrvale ilmuvad leheserva pelgalt teoreetikute - aga ka kirjanike, nagu luuletaja Eileen Myles jt - nimed, kelle ideed parajasti Nelsoni enda arutlusega haakuvad. Teoreetik ei pane asja paika. Pigem viidatakse talle kui kaasteelisele, kellega lugeja võib, aga ei pea suhestuma. Ka Kangro tekstist kajavad vastu loetud teoreetilised ja ilukirjanduslikud tekstid, kuid need sageli lohutud viited ei selgita minajutustaja kogemust, vaid annavad sellele distantseeriva kõrvaltpilgu. Teooria on vaid üks võimalik lugemise võti ning see võti tuleb

${ }^{19}$ Siin nimetatud teoreetikutest viitab Nelson küll vaid kaude Irigarayle ja Kristevale. Nelson pole ka ainuke, kes emadusest kirjutades tõukub Barthes'ist. Nt 1990. aastate alguse autobiograafilises kriitikas kirjeldas Julia Balén oma raseduskogemust läbi Barthes’i „Tekstimõnu” ja selle väite, et keha ja mina mõtted lähevad lahku (Balén 1993: 293). 
lugejal enda jaoks kasutuskõlbulikuks teha, sest autoteoreetiline tekst ei anna bibliograafiat ega isegi konkreetset tsitaati. Teksti fookuses on meile ilmnev, küll värelevate piirjoontega, teine mina. Kangro tekstis on selleks sündimata jäänud „tibu”.

Teooriat ei kasutata kogemuse selgitamiseks ega kogemust teooria illustratsiooniks, vaid kogemuse abil testitakse teooriat - ja nii mitmedki ideed heidetakse üle parda. Nelsoni tüüpiline kommentaar psühhoanalüütilisele tsitaadile seksuaalsuse kohta on: „Mind hämmastab ja paneb häbi tundma mõte, et aastaid olid sellised küsimused minu jaoks mitte ainult arusaadavad, vaid ka põnevad" (Nelson 2015: 20). Teooria näidatakse sellistel juhtudel kogemuse proovikivile mitte vastu pidavat, abstraktsete teoreetiliste diskussioonide nautimine nende endi pärast näib piinlikkust tekitav.

Teooriat küsimärgistatakse kokkupuutes muutuva kehalise reaalsusega (aga ka poliitilise reaalsusega: teksti kirjutamise ajal käib Californias debatt samasooliste abielude üle). Teoreetikute kõrval leiab ääretsitaatides, eriti mida enam me liigume raamatu lõpu poole, mainimist minajutustaja elukaaslane. Nelsonit huvitab „tegelikkuse tundmine”, jagatud elusolemise tunnetus (Nelson 2015: 14). Nelsoni teose lõpus ei jõuta mingile teoreetilisele järeldusele, kõlama ei jää mitte teadmine, vaid hool ja kogetud „nüüd” (Nelson 2015: 143). Raamat lõpebki selle sõnaga.

Kangro teksti afektiivne laeng on oma traumaatilisuses võimsam. Raamatu lõpetab teadmine, et loode, kelle minajutustaja soovis matta, oli põletatud: „Tibuke, minu väike neiu, kes ei vaadanud mind etteheitva näoga. Minu väike ilus mitteisik. Nüüd oli ta ära põletatud, koos võõraste amputeeritud jäsemete ja eemaldatud kudedega.” (Kangro 2016: 205) Ka Kangro minajutustaja jääb pidama olevikulisse ajahetke, kuid selles domineerib pigem eluõud, mille eest võib püüda põgeneda, aga mis meid ikkagi kätte saab. Selles lõigus aga ei puudu ka hellus, teadmine, et sündimata laps teda hukka ei mõista, sest ta on „hea laps” (Kangro 2016: 190).

Abby Paige rõhutab, et Nelson näib kahtlustavat kõike, mis on kategooriline. Nelsonit huvitab muu: „Paradoks on midagi enamat kui vastandlike väidete või impulsside kooseksisteerimine. See osutab võimalusele, et eksisteerib - ja vahel ka ilmneb - kolmas termin situatsioonis, kus muidu näisid vastakuti seisvat vaid kaks jõudu." (Paige 2015) See kolmas termin ei anna tunnistust otsustamatusest, nagu Paige märgib, vaid on pigem tundlik ja koostööaldis ala, mis on piisavalt avatud, et suuta sisaldada ka vastuolusid. Nelson - ega ka Paige - ei tõmba otsest paralleeli Homi Bhabha mõistega kolmas ruum (ingl third space), mis tähistab vaheala, kus identiteedid on pidevas hübriidses muutumises (Bhabha 2004: 50). Nelsoni enesekirjutus aga püüdleb selgelt samasuguse pidevas muutumises oleva hübriidse enesekäsitluse poole. Ka Kangro enesekirjeldus on pidevas muutumises, kuigi tema narratiivis on tugevamalt esil selgesilmne, kogetut lahkav, subjektne kirjutav mina. Samal ajal on see mina teadlik tunnete vastuolulisusest, nende sobimatusest üheselt defineerivasse, mittemõtlevasse peavoolukultuuri.

Kahevahelolek tundub binaarsele ja heteronormatiivsele maailmale olemuselt ohtlik, sest ärritab mõlemat vastaspoolt, keeldudes nende vahel valimast. Nelsonit see ei hirmuta, sest ta püüab binaarset mõtlemist lõhkuda, küll aga huvitab teda, kuidas silte eirav mina saab arusaadavana, kirjutatavana eksisteerida maailmas, mis on üles ehitatud selgepiirilistele siltidele; kus sadamasse naasnud Argo olemuse üle ei muretseta, kui nimi ja väline vorm 
kokku langevad. Sara Ahmed (2006: 179) küsib, mis positsiooni me võtame, kui kohtume erineva, hälbelisega, millegagi, mis kuhugi ei kuulu. Ahmed näeb meie sättumuste taga teatud orienteeritust ruumis ja meiega ruumi jagavate teiste suhtes. Meie orienteeritus teeb mingid asjad võimalikuks, mingid võimatuks. Nelsoni autoteoreetiline ruum on avatud hübriidsele, kuid samas on teadlik siltide lummusest, siltideta kirjelduse keerukusest. See pakub meile kogukonda, kus me saame kaasa mõelda omaenda orienteerituse üle meist erinevate, meie silte ebapiisavaks pidavate teiste suhtes. Sellisena on Nelsoni autoteoreetiline tekst katse luua kirjanduslikku kolmandat ruumi. Kangro tekstis on sildistamatusel teine tähendus. See viitab pigem abjektsele, kultuuris alla surutud kehalisele ja emotsionaalsele kogemusele.

Ei Nelson ega Kangro soovi teoretiseerida, vaid konkretiseerida. Rääkides naise kehast, ei ole tegu ju abstraktse debatiga naiste valikuvõimaluste ja väärarenguga loote eluõiguse vahel, nagu seda poliitikas või ka lihtsustatud meediatekstides sageli kohtame. Sama käib seksuaalsete eelistuste ja praktikate kohta: reaalses elus ei pane meil südant peksma mitte silt või hermeneutika, vaid konkreetne inimene. Nelson ja Kangro ei võimalda lugejal õdusale pihtimusnarratiivile keskenduda, vaid sunnivad meid oma kogemusi, aga ka oma poliitilisi ja filosoofilisi ideid hindama. Me võime autoritega mitte nõus olla, nende ideede radikaalsuse või enesepaljastuse printsipiaalsuse peale ärrituda, aga me lahkume tekstist tugeva emotsionaalse laenguga ja suutmatusega omaenda ambivalentseid kogemusi kalevi alla panna. Need tekstid pääsevad meile naha alla ning meenutavad, nagu Kangro ütleb, et „sügavas pasas ujuma peab igaüks ise" (Kangro 2016: 21) - kuid samal ajal annavad meile ka keele, et rääkida sellest, millest tavaliselt vaikitakse.

Ehk on üheks põhjuseks see, et ei Nelsoni ega Kangro raamatus ei hakka abstraktne keel autori enda häält ega kogemust kunagi allutama. Teoreetikute nimed on Nelsonil diskreetselt saadetud teksti servadele, mitte jõuliselt pikkade tsitaatide või joonealuste märkustega varustatult teksti keskele. Kangro tekstis on meditsiiniliste terminite keel esil, aga mitte tõe allikana; tekstis mainimist leidvad kirjanikud-kunstnikud ei summuta Kangro häält. Teised ei dikteeri mõttevoogu, vaid neid kantakse sellega kaasa. Keel pole selles protsessis alati autori liitlane, sest sunnib näiteks Nelsonit valima inglise keeles nais- ja meessoole viitavate asesõnade vahel, mis on tema muutuva sooga partneri puhul probleem. Ta kirjeldab elavalt asesõnade vältimist, grammatilist žongleerimist ja nime kordamisest tekkivat konkreetsust, pidevat vajadust seletada, samal ajal teades, et seletus on ebapiisav, kuna sõnade tõmmatavad piirid ei peegelda inimkogemuse voolavust (Nelson 2015: 7). Kangro puhul tekitab takistuse meditsiinilise terminoloogia ja kogeva keha vaheline kuristik. Silt ei ole piisav, kuid samas on silt, nimi, kultuuris arusaadav kirjeldus see, mis teeb meie kogemuse teistele arusaadavaks, ning Nelsoni ja Kangro tekste täidab just nimelt tung jutustada oma lugu, teha oma kogemus kultuuriliselt mõistetavaks, luues ruumi neile, kelle enda mina samalaadselt kultuuriliste narratiividega ei samastu.

See omakorda toob välja meie tavapärase harjumuse märkida inimesi binaarsete sooliste siltidega (ja minagi pean piinlikkusega tunnistama, et ma guugeldasin, saamaks teada, kes Nelsoni elukaaslane siiski „päriselt on”, sest silditu, mittebinaarne isik ei andnud rahu). Nelson teab, kes on tema elukaaslane, mida ta tema vastu tunneb, kuid (inglise) keel ei võimalda tal sellest adekvaatselt kirjutada. Kangro suudab oma kogemust kirjeldada rabava otse- 
kohesusega kogu selle abjektsuses, kuid näitab vastuoluliste kultuuriliste narratiivide suutmatust kogemusele koherentset tähendust anda. „Sõnadest ei piisa", nendib Nelson juba raamatu alguses ja kordab mitmel korral, samas rõhutades ka vajadust teatud asju oma sõnadega lausuda (Nelson 2015: 4, 70). See on olulisem kui teoreetikute tsitaatide aukartlik kordamine akadeemilistes tekstides. Nelson proovib lahti harutada, miks ta kirjutab ja miks ta tunneb, et suudab oma ja lähedase teise kogemusest kirjutada (Nelson 2015: 3).

Nelson ja Kangro otsivad tekstis võimalust luua keeles koht, kus saab olla ja kogeda mittebinaarselt, reflekteerides oma valikuid, normide mõju, teiste poolt pandud silte ja vabadust. Eraeluline on poliitiline ja me ei saa neid kahte sfääri lahutada. Nelsoni ja Kangro näiliselt ebamugavalt enesekeskne projekt puudutab mitmeid tänase päeva põletavaid poliitilisi küsimusi, mis on seotud emaduse, reproduktsiooni ja soopoliitikaga. Selles kogu teksti spiraalselt läbivas liikumises kogemuse, teoreetiliste küsimuste ja poliitika vahel avaldubki teksti autoteooria. Nelsoni ja Kangro kogemus, afektid ja emotsioonid on personaalsed, aga samas ristuvad teiste omadega ja laiema poliitilise kontekstiga.

Paige märgib, et Nelson mitte „niivõrd ei painuta žanri oma vajaduste järgi, kui keeldub ennast painutamast žanrinõuete järgi, ning just see paindumatus teeb tema teose nii värskeks, nii haaravaks, nii tumedaks ja nii intiimseks" (Paige 2015). Sama võib julgelt öelda ka Kangro kohta ning tema teksti senine retseptsioon on sellele samuti selgelt tähelepanu juhtinud. Nagu artikli alguses öeldud, paneb žanrimääratlus paika teksti pragmaatilise, aga ka afektiivse ja emotsionaalse diapasooni, ning Nelson ja Kangro suudavad võõritusefekti tuua nii emadusnarratiivi, feministlikku omaeluloolisusesse kui ka teoreetilisse mõtisklusse. Nelsoni eesmärk, nagu ta ühes intervjuus ütleb, on leida vorm, mis aitaks taasluua kogemust sellisena, nagu ta on, ilma žanrikonventsioonide normidesse takerdumata. Vorm on oluline ning Nelson väidab ennast keskenduvat just esteetilistele probleemidele, sest tema kogemuse järgi toob nende lahendamine kaasa ka psühholoogiliste või teoreetiliste probleemide lahendamise, kas või kaudselt (McCrary 2015). Julgeksin sama väidet laiendada ka Kangro tekstipraktikale. Just seetõttu on need kaks väga erineva afektiivse laenguga teksti autoteooria heaks näiteks.

Need tekstid on sõna otses mõttes näited keha kaudu väljendatud mõtteprotsessist. See pääseb naha alla, paneb vaidlema, kaasa mõtlema, aga ka kaasa elama ja oma kogemust testima. Tänane autoteooria räägib kirega, mida pole teoreetilises kirjanduses feministliku personaalse kriitika aegadest kuulda olnud. Ta räägib aga valdavalt mitte teooria, vaid just kirjanduse ja omaeluloolisuse kontekstis, kus kahtluse hermeneutika pole tundeid alla surunud. Tegemist võib olla personaalse kriitika teise tulemisega, aga oluline pole mitte see, vaid värske isikliku hääle naasmine teoorialoomesse. Autoteooria meenutab meile, et omaelulooline narratiiv on võimas tekstivorm, mis ei aita meil süüvida mitte ainult ühe inimese kogemusse, vaid annab teooriale uue hingamise, näitab selle hädavajalikkust inimese kehastunud kogemuse seletamisel. Autoteooria on mikropoliitiline ning toimib üksikisiku tasandil, aga just sellisena on tal tugev poliitiline potentsiaal, sest ta sunnib lugejat kaevuma omaenda kogemusse, väärtustesse, arvamustesse ja seda mitte ainult abstraktse teoreetilise harjutusena. 
Artikli valmimist on toetanud Euroopa Liit Euroopa Regionaalarengu Fondi kaudu (Eesti-uuringute Tippkeskus), see on seotud Eesti Haridus- ja Teadusminiteeriumi uurimisprojektiga PUT1481 „Imaginaarsete narratiivsete stsenaariumide roll kultuuridünaamikas”. Tänan Leena Kurvet-Käosaart toetavate ja konstruktivsete nõuannete eest.

\section{Kirjandus}

A h med, Sara 2004. The Cultural Politics of Emotion. London: Routledge.

Ah med, Sara 2006. Queer Phenomenology: Orientations, Objects, Others. Durham: Duke University Press.

Alc off, Linda 1988. Cultural feminism versus post-structuralism: The identity crisis of feminist theory. - Signs, kd 13, nr 3, lk 405-436.

Bal, Mieke 2015. Documenting what? Auto-theory and migratory aesthetic. A Companion to Contemporary Documentary Film. Toim Alexandra Juhasz, Alisa Lebow. Oxford: Wiley Blackwell.

Balé n, Julia 1993. La Ronde of children and mothers. - The Intimate Critique: Autobiograhical Literary Criticism. Toim Diane P. Freedman, Olivia Frey, Frances Murphy Zauhar. Durham: Duke University Press.

Bals a m o, Anne Marie 1996. Public pregnancies and cultural narratives of surveillance. - A. Balsamo, Technologies of the Gendered Body: Reading Cyborg Women. Durham: Duke University Press, lk 80-115.

B arthes, Roland 1972. Critical Essays. Tlk R. Howard. [Evanston:] Northwestern University Press.

B arthes, Roland 1977. Roland Barthes by Roland Barthes. Tlk R. Howard. Berkeley: University of California Press.

Bh a b ha, Homi 2004. The Location of Culture. Abington: Routledge.

C a v a r e r o, Adriana 2000. Relating Narratives: Storytelling and Selfhood. London: Routledge.

D u Ples s is, Rachel Blau 2009. Gender buttons. - Australian Literary Studies, kd 24, nr 3-4, lk 20-38.

E aki n, Paul John 1992. Touching the World: Reference in Autobiography. Princeton: Princeton University Press.

Felski, Rita 2011. Suspicious minds. - Poetics Today, kd 32, nr 2, lk 215-234.

F i s ch er, Clara 2016. Feminist philosophy, pragmatism, and the „turn to affect”: A geneaological critique. - Hypatia, kd 31, nr 4, lk 810-826.

Gregg, Melissa, Seigw orth, Gregory J. (toim) 2010. The Affect Theory Reader. Durham: Duke University Press.

H e m m in g s, Clare 2005. Invoking affect: cultural theory and the ontological turn. - Cultural Studies, kd 19, nr 5, lk 548-567.

Hester, Helen [2013]. Synthetic Genders and the Limits of Micropolitics. ... ments, $\mathrm{nr}$ 6. http://journalment.org/article/synthetic-genders-and-limitsmicropolitics (5. VIII 2017).

Hollo, Maarja 2017. Rännak kannatuse linnades. - Keel ja Kirjandus, nr 2, lk 133-136.

Irigaray, Luce 1985. This Sex Which Is Not One. Ithaca: Cornell University Press.

Jagg ar, Alison 1989. Love and knowledge: emotion in feminist epistemology. Inquiry: An Interdisciplinary Journal of Philosophy, kd 32, nr 2, lk 151-176. 
Kang r o, Maarja 2016. Klaaslaps. Tallinn: Nähtamatu Ahv.

Ka pil, Bhanu 2015. Ban en Banlieu. Callicoon: Nightboat Books.

Ka ufm an n, Jodi 2005. Autotheory: an autoethnographic reading of Foucault. Qualitative Inquiry, kd 11, nr 4, lk 576-587.

Kurvet-Käosaar, Leena 2016. Enese ilmnemine/ilmutamine Viivi Luige romaanis „Varjuteater”. - Adressaadi dünaamika ja kirjanduse pingeväljad. Toim L. Kurvet-Käosaar, Marin Laak. (Studia litteraria Estonica 18.) Tartu: Tartu Ülikooli Kirjastus.

L or d e, Audrey 1984. Sister Outsider. New York: Ten Speed Press.

M c Cr a ry, Micah 2015. Riding the Blinds. Micah McCrary interviews Maggie Nelson. - Los Angeles Review of Books, 26. IV. https://lareviewofbooks.org/article/ riding-the-blinds/ (5. VIII 2017).

Miller, Carolyn R. 1984. Genre as social action. - Quarterly Journal of Speech, kd 70, lk 151-167.

Mille r, Nancy K. 1991. Getting Personal. Feminist Occasions and Other Autobiographical Acts. New York-London: Routledge.

Miller, Nancy K. 2011. What They Saved: Pieces of Jewish Past. Lincoln: University of Nebraska Press.

Modleski, Tania 1991. Feminism Without Women: Culture and Criticism in a „Postfeminist” Age. New York: Routledge.

Mo i, Toril 1988. Feminism, postmodernism, and style: recent feminist criticism in the United States. - Cultural Critique, nr 9, lk 3-22.

Mo i, Toril 2006. „I Am Not a Feminist, But...”: How Feminism Became the F-Word. - PMLA, kd 121, nr 5, lk 1735-1741.

Mo i, Toril 2015. „Ma ei ole naiskirjanik”: naistest, kirjandusest ja feministlikust teooriast tänapäeval. - Ariadne Lõng, kd 15, nr 1/2, lk 153-163.

Nel s o n, Maggie 2015. The Argonauts. Minneapolis: Graywolf Press.

Nich ols o n, Linda (toim) 2006. Feministlikud vaidlused: filosoofiline mõttevahetus. Tlk Merilin Sikk. Tallinn: Tallinna Ülikooli Kirjastus.

Paige, Abby 2015. Queering the momoir. - Los Angeles Review of Books, 26. IV. https://lareviewofbooks.org/article/queering-the-momoir/ (5. VIII 2017)

Patai, Daphne, Corral, Will H. (toim) 2005. Theory's Empire: An Anthology of Dissent. New York: Columbia University Press.

Preci ad o, Paul B. 2013. Testo Junkie. New York: Feminist Press.

Renders, Hans 2014. Roots of biography: from journalism to pulp to scholarly based non-fiction. - Theoretical Discussions of Biography: Approaches from History, Microhistory and Life Writing. Toim H. Renders, Binne de Haan. Leiden: Brill.

Rich, Adrienne 1976. Of Woman Born: Motherhood as Experience and Institution. New York: Norton.

Rich, Adrienne 1986. Notes Towards a Politics of Location. - A. Rich, Blood, Bread, and Poetry: Selected Prose, 1979-1985. New York: W.W. Norton, lk 210-231.

Ricoeur, Paul 1970. Freud and Philosophy: An Essay on Interpretation. New Haven: Yale University Press.

Ruddick, Sara 1995. Maternal Thinking: Towards a Politics of Peace. New York: Beacon.

Ry an, Judith 2014. The Novel After Theory. New York: Columbia University Press.

S a k ov a, Aija 2017. Maailm sita eituseta. - Sirp 3. II. 
Sedgwick, Eve Kosofsky 1987. A Poem is Being Written. - Representations, nr 17, lk 110-143.

Sedgwi ck, Eve Kosofsky 2003. Touching Feeling: Affect, Pedagogy, Performativity. Durham: Duke University Press.

Seigel, Marika 2013. The Rhetoric of Pregnancy. Chicago: University of Chicago Press.

Sh ow alt er, Elaine 1981. Feminist criticism in the wilderness. - Critical Inquiry, kd 8, nr 2, lk 179-215.

Smith, Sidonie, Watson, Julia 1998. Introduction: situating subjectivity in women's autobiographical practices. - Women, Autobiography, Theory: A Reader. Toim S. Smith, J. Watson. Madison: The University of Wisconsin Press. To m pkins, Jane 1987. Me and my shadow. - New Literary History, kd 19, nr 1, lk 169-178.

Young, Iris Marion 1984. Pregnant embodiment: subjectivity and alienation. Journal of Medicine and Philosophy, kd 9, nr 1, lk 45-62.

Young, Stacey 1997. Changing the Wor(l)d: Discourse, Politics and the Feminist Movement. New York: Routledge.

\section{The possibilities of autotheory between theory and life writing}

Keywords: life writing, embodied theory, affect theory

The article focuses on texts that can be classified as autotheoretical, that is, they are autobiographical texts that simultaneously interrogate theoretical issues and, by their genre liminality, seek to articulate otherwise muted phenomena. The autotheoretical practice of the 2000 s can be seen as a continuation of feminist personal criticism of the 1970s-1980s, such as the work of Jane Tompkins and Nancy K. Miller, and an attempt to develop forms of writing outside the prevalent academic hermeneutics of suspicion. Proceeding from the work of Mieke Bal, Roland Barthes and Adriana Cavarero, the article aims to show the productivity of this movement between embodied experience, autobiography, fiction and theoretical reflection. As such, it is also a reflection on the political and affective affordances of different genres, as well as the promise of reparative reading suggested by Eve Kosofsky Sedgwick.

The theoretical discussion is illustrated with examples from two hybrid texts dedicated to an honest and at times discomforting discussion of reproduction, maternity, and the family: Maggie Nelson's critically acclaimed „The Argonauts” (2015) and Maarja Kangro's „Klaaslaps” („Glass Child”) (2016), an equally celebrated Estonian text. Both texts emerge as good examples of autotheoretical writing that evoke a series of political and theoretical reflections, expanding the pragmatic and affective range of autobiographical writing and exploring its aesthetic possibilities. Autotheory is micro-political, but it is precisely because of this subjective focus that it compels its readers to engage with their own experience and opinions. As such, these texts and others following their practice can contribute to enlivening today's feminist and gender theory.

Raili Marling (b. 1973), PhD (English language and literature), College of Foreign Languages and Cultures, University of Tartu, Associate Professor, raili.marling@ut.ee 